Abstract-From 2003 to 2006, 44,882 Yellowtail Flounder (Limanda ferruginea) were captured and released with conventional disc tags in the western North Atlantic as part of a cooperative Yellowtail Flounder tagging study. From these releases, 3767 of the tags were recovered. The primary objectives of this tagging program were to evaluate the mortality and large-scale movement of Yellowtail Flounder among 3 stock areas in New England. To explore mortality, survival and recovery rate were estimated from traditional Brownie tag-recovery models fitted to the data with Program MARK. Models were examined with timeand sex-dependent parameters over several temporal scales. The models with a monthly scale for both survival and recovery rate had the best overall fit and returned parameter estimates that were biologically reasonable. Estimates of survival from the tag-recovery models confirm the general magnitude of total mortality derived from age-based stock assessments but indicate that survival was greater for females than for males. In addition to calculating mortality estimates, we examined the pattern of release and recapture locations and revealed frequent movements within stock areas and less frequent movement among stock areas. The collaboration of fishermen and scientists for this study successfully resulted in independent confirmation of previously documented patterns of movement and mortality rates from conventional age-based analyses.

Manuscript submitted 9 April 2012 Manuscript accepted 31 May 2013. doi 10.7755/FB.111.3.6

Fish. Bull. 111:279-287 (2013).

The views and opinions expressed or implied in this article are those of the author (or authors) and do not necesarily reflect the position of the National Marine Fisheries Service, NOAA.

\title{
Mortality and movement of Yellowtail Flounder (Limanda ferruginea) tagged off New England
}

\author{
Anthony D. Wood (contact author)' \\ Steven X. Cadrin ${ }^{2}$ \\ Email address for contact author: anthony.wood@noaa.gov \\ 1 Northeast Fisheries Science Center \\ National Marine Fisheries Service, NOAA \\ 166 Water Street \\ Woods Hole, Massachusetts 02543 \\ 2 School for Marine Science and Technology \\ University of Massachusetts Dartmouth \\ 200 Mill Road, Suite 325 \\ Fairhaven, Massachusetts 02719
}

The Yellowtail Flounder (Limanda ferruginea) is one of the principal resources of the groundfish complex in the northeastern United States, with major fishing grounds on Georges Bank, off southern New England, and off Cape Cod. The fishery for Yellowtail Flounder is among the most productive and valuable in New England, yielding 1832.5 metric tons and $\$ 4.78$ million to U.S. fishermen in 2011 (NMFS, 2012). However, the potential yield of Yellowtail Flounder is much greater than the current yield. The estimated maximum sustainable yield from the 3 stocks in New England is 29,483.5 metric tons $\left(\mathrm{NEFSC}^{1}\right)$. The 3 stock areas examined in this study were Cape CodGulf of Maine, Georges Bank, and southern New England-Mid-Atlantic.

Despite substantial investments in sampling Yellowtail Flounder fisheries and resources, uncertainty persists in the age-based stock assessments from the 2008 Groundfish Assessment Review Meeting of

${ }_{1}$ NEFSC (Northeast Fisheries Science Center). 2008. Assessment of 19 northeast groundfish stocks through 2007: report of the 3rd Groundfish Assessment Review Meeting (GARM III), Northeast Fisheries Science Center, Woods Hole, MA, 4-8 August 2008. NMFS, Northeast Fish. Sci. Cent. Ref. Doc. 08-15, 884 p. + xvii. [Available from National Marine Fisheries Service, 166 Water Street, Woods Hole, MA 02543-1026.]
Northeast Fisheries Science Center $\left(\mathrm{NEFSC}^{1}\right)$. The sources of this uncertainty are not well understood but may result from the movement of flounder among stock areas, lack of information on the effect of closed areas on population dynamics, insufficient surveying of areas closed to fishing, inaccurate age determinations, misrepresentative sampling of distributional patterns, underreported catch, or inaccurate assumptions about natural mortality (NEFSC ${ }^{1}$ ). In 2002, a cooperative tagging study was designed to provide independent information on mortality and movement, to complement the current stock assessment methods for Yellowtail Flounder, and to improve the reliability of scientific advice for effective fishery management $\left(\mathrm{NEFSC}^{2}\right)$.

Movement of Yellowtail Flounder off New England has been addressed

\footnotetext{
${ }^{2}$ NEFSC (Northeast Fisheries Science Center), Workshop Organizing Committee (S. Tallack, ed., P. Rago, chairperson, T. Brawn, workshop coordinator, and (alphabetically) S. Cadrin, J. Hoey, and L. Taylor Singer). 2005. Proceedings of a workshop to review and evaluate the design and utility of fish mark-recapture projects in the northeastern United States; Nonantum Resort, Kennebunkport, Maine, 19-21 October 2004. U.S. Dep. Commer., Northeast Fish. Sci. Cent. Ref. Doc. 05-02; 141 p. [Available from National Marine Fisheries Service, 166 Water St., Woods Hole, MA 025431026.]
} 
by several historical and more recent tagging studies. A study that examined fish tagged and released off the northeastern coast of the United States from 1942 to 1949 concluded that groups were relatively localized and exhibited short seasonal migrations. Most tagged fish were recovered within $80 \mathrm{~km}$ of the release site and little mixing was observed between fishing grounds, except for frequent movement from the Mid-Atlantic Bight to the waters of southern New England (Royce et al., 1959). Lux (1963) confirmed these observations and concluded that groups of Yellowtail Flounder move seasonally within fishing grounds, and a small amount of seasonal mixing occurs among groups. More recent tagging studies of Yellowtail Flounder in Canadian waters have confirmed the sedentary nature of this species. Fish tagged from 3 studies on the Grand Bank, Canada, traveled an average of $59 \mathrm{~km}$ (Walsh and Morgan, 2004). A recent summary of all previously published studies that detailed Yellowtail Flounder movements off the northeastern United States indicated 95\% residence in current stock areas (Cadrin, 2010).

The cooperative Yellowtail Flounder tagging study described in this article was designed to address sources of uncertainty in Yellowtail Flounder stock assessments. Two objectives of this study were to provide 1) estimates of mortality independent of mortality estimates from current Yellowtail Flounder stock assessments and 2) extensive release and recovery information and documentation of movement of fish between stock areas.

\section{Materials and methods}

The general approach to tagging in this study involved a sampling design with geographic coverage that represented the entire Yellowtail Flounder resource off New England. All phases of the proposed research, from the field protocol to public outreach, were developed cooperatively with New England groundfish fishermen. We contracted commercial fishermen and their vessels to work with scientists to tag and release fish in all stock areas. The geographic design was developed on the basis of fishing areas, with releases in each area proportional to values of relative abundance of Yellowtail Flounder from groundfish surveys conducted by the Northeast Fisheries Science Center. The field protocol and analytical design were considered during peer review to be valid approaches to meet the objectives of this tagging study (NEFSC ${ }^{2}$.

Fish were captured with commercial otter trawls or gillnets with large mesh $(16.5 \mathrm{~cm})$ and relatively short trawl tows $(30 \mathrm{~min})$ or gillnet sets $(<6 \mathrm{~h})$. Yellowtail Flounder were identified by using Collette and Klein-MacPhee (2002). All legal-size fish $(>33 \mathrm{~cm}$ in fork length) in viable condition, and some sublegal-size fish from tows in low-density areas, in the southern New England-Mid-Atlantic stock area were tagged with Petersen disc tags (22-mm in diameter). Viability was classified as excellent, good, or poor. Excellent fish exhibited body flexion and operculum or mouth movement, and no apparent damage from capture. Good fish also exhibited activity but had minor damage (e.g., scale loss, minor abrasion, and net marks). Poor fish, which exhibited no activity and had major abrasions or bleeding, were not tagged. Fish were released during the spawning season (May-August), with the exception of $1 \%$ of the releases, which occurred in the autumn of 2003 .

Tags were collected from fish recaptured from a year-round commercial fishery with some seasonal geographic closures. The reward system for reporting recaptures included a $\$ 1000$ lottery for all returned tags and 280 high-value (\$100) rewards. The outreach system involved reward posters, brochures, a website (http://www.cooperative-tagging.org), annual letters to Yellowtail Flounder fishermen, press releases, and a toll-free phone number. Patterns of tag-recovery rates were analyzed statistically with contingency tables $(G-$ test; Sokal and Rohlf, 1995) of frequencies of releases and reported recaptures by sex, size, condition code, and damage code.

To analyze the Yellowtail Flounder tagging data, Program MARK was used to fit multiperiod tagging models (White and Burnham, 1999). Program MARK facilitates the application of various types of markrecapture models and estimates model parameters through the use of maximum likelihood. Brownie-type dead-recovery models (Brownie et al., 1985) were used to estimate the probability of Yellowtail Flounder survival $(S)$ and a recovery rate probability (f). Recovery rate in this study was a compound parameter that represented the probabilities that a tagged fish was captured, the tag was retrieved, and the tag was reported. The model assumes that the probabilities of survival and recovery are the same for all marked animals and that tagging is instantaneous during sampling occasions.

A preliminary analysis, in which alternative tagging models with time-steps over different temporal scales (weekly, monthly, biannual and annual) were examined, indicated that the data were best suited for models with a monthly time step. Recovery data were entered into Program MARK with a classic recovery matrix format (Brownie et al., 1985; White and Burnham, 1999). The recovery matrix was examined with a suite of models that exhibited both time-dependent and constant survival, as well as time-dependent and constant recovery rate. Sex was included in the model as a group effect on survival and recovery rate. In addition, commercial catch was used as a proxy for fishing effort and was explored as a covariate on recovery rate in multiple models. Matrices of expected values were developed for each model, and recoveries were modeled as multinomial random variables. Parameters were estimated with maximum likelihood estimation.

Akaike's information criterion (AIC) was used to rank and select the model that achieved an optimal 
balance between the parsimony of the model and the goodness-of-fit, where parsimony decreases as the number of parameters in the model increases. Model fit was judged with the model likelihood $(L)$ :

$$
\mathrm{AIC}=2 K-2 \ln (L),
$$

where $K=$ the number of parameters.

To determine whether the general model (fully parameterized) was a reasonable fit to the tag-recovery data, goodness-of-fit was tested. A simulation procedure was used to calculate an estimate of overdispersion $(\hat{c})$. Data were simulated at varying levels of overdispersion ( $\operatorname{simulated} c$ ), and the deviance of each data set was divided by the degrees of freedom to obtain a range of values. A logistic regression was used to estimate the level of $\hat{c}$ where $50 \%$ of the simulated values were above and $50 \%$ were below the observed deviance divided by degrees of freedom of the general model. A model solution that perfectly conforms to the assumed error distribution would produce an expected variance equal to the observed variance and would have a $\hat{c}$ value of 1.0. Deviations of $\hat{c}$ above or below 1.0 indicate over- or underdispersion, respectively. Generally, a $\hat{c}$ value $>3.0$ indicates poor model fit because the model deviance is greater than the expected deviance (Lebrenton et al., 1992; Burnham and Andersen, 2002).

To account for $\hat{c}$ and for differences in effective sample size $(N)$, a quasi-likelihood adjusted AIC $\left(\mathrm{QAIC}_{\mathrm{c}}\right)$ was used to adjust fit of the top selected models (Anderson et al., 1994; Burnham and Anderson, 2002):

$$
Q A I C_{c}=2 K+\frac{-2 \ln (L)}{\hat{c}}+\frac{2 K(K+1)}{N-K-1} .
$$

The adjusted results from the top ranked models determined through the model selection criterion were then examined for biologically realistic parameter estimates. Models that estimated multiple parameters at their boundaries (e.g., $S=1.0$ ) were rejected in favor of the next ranked model.

\section{Results}

Researchers worked with commercial fishermen to tag 44,882 Yellowtail Flounder with conventional disc tags, and 3767 of these tags were recovered from the commercial fishery. Of all the lottery tags and $\$ 100$ highreward tags, $8 \%$ and $14 \%$ were returned, respectively. The relative return rate of lottery tags to high-value tags indicates a 59\% reporting rate, assuming that $100 \%$ of the high-reward tags were reported (Table 1 ). The results from the analysis of observed recovery rates by sex, size, condition code, and damage code indicate that females had a greater recapture rate than males (particularly small males). Fish categorized as good had the same recovery rates as fish that were excellent. All damage codes had similar recovery rates, except for the slightly lower recovery rates for those

\section{Table 1}

Total releases and recaptures of tagged Yellowtail Flounder (Limanda ferruginea) by tag type from 2003 to 2006 in a cooperative tagging study off New England. The ratio of recovery rate from lottery tags and highvalue tags indicates a 59\% reporting rate, assuming $100 \%$ reporting of high-value tags.

\begin{tabular}{lccc}
\hline Tag type & Releases & Recovered & $\begin{array}{c}\text { Percentage } \\
\text { recovered }\end{array}$ \\
\hline Lottery tags & 44,501 & 3713 & 8.3 \\
$\$ 100$ tags & 381 & 54 & 14.2 \\
Total & 44,882 & 3767 & 8.4 \\
\hline
\end{tabular}

fish with net marks (5\% recovered) and those showing evidence of lymphocystis (3\% recovered).

Releases occurred in monthly batches over a 39-month period from June 2003 to August 2006, mostly in summer (Fig. 1). The full recovery matrix (with known month of capture) included a total recapture rate of $7.9 \%$ (Table 2 ). There was a higher rate of recapture for females $(8.4 \%)$ than for males $(6.5 \%)$.

\section{Mortality}

The release and recovery data were audited, and only tags with both location and fish sex information were included in the modeling. The final recovery matrix used to estimate survival included 43,907 releases and 3457 recaptures. Several model variations with both time-dependent and time-independent parameter estimates and with sex-dependant parameter estimates were successfully fitted to the data.

All of the top-ranked models determined through model selection had a time-dependent recovery rate parameter $\left(f_{\mathrm{t}}\right)$ with varying levels of sex dependence on both recovery rate and survival $\left(S_{\mathrm{g}}\right)$. Results from procedures for the simulation of goodness of fit indicate that the general model fitted the tag-recovery data well, returning a $\hat{c}$ estimate of 2.12 (Fig. 2). After the goodness-of-fit adjustment to the models, full weight was given to the model with a time-dependent survival and time-dependent sex-specific recovery rate. The 2 best models had a time-dependent survival estimate. However, many of the estimates were at the upper boundary of survival $(S=1.0)$ because of sparseness in the data, and therefore the 2 models with time-dependent survival were not considered. The optimum model was a model with constant survival and time- and sex-dependent recovery rate (Table 3 ). On the basis of goodness-of-fit and model validation diagnostics, the optimum model appears to be a reliable representation of the data.

A constant rate of survival of $0.89 /$ month with a standard error of 0.016 was estimated from the best model. The annual rate of survival was calculated at 


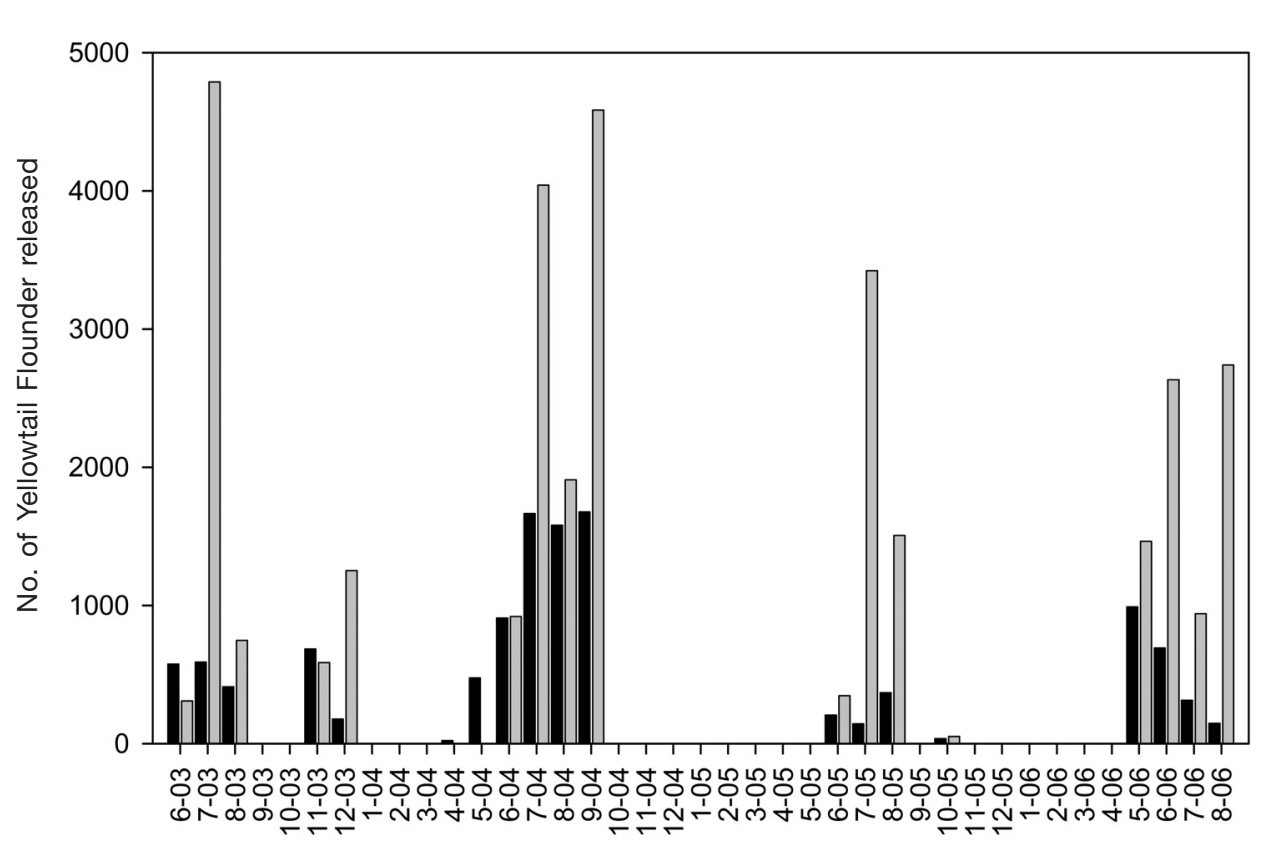

Figure 1

Number of tagged Yellowtail Flounder (Limanda ferruginea) released by month off New England from June 2003 to August 2006 for this tagging study. Black bars indicate males released, and light gray bars indicate females released.

0.25 , a value equivalent to a total annual mortality $(Z)$ of 1.4. Abundance-weighted $F$-values for age $6+$ Yellowtail Flounder from an age-based stock assessment were $0.49,1.49,1.01$, and 0.85 , for the years from 2003 to 2006 , respectively. The tag-based estimate of $Z$ is within the range of these stock-assessment $F$-values, assuming a natural mortality of 0.2 for these years (Fig. 3). Estimates indicate that recovery rates ranged from 0.001 to 0.078 for males and 0.001 to 0.037 for females. Noticeable peaks in the recovery rate for females were observed in the period of May-August of each year (Fig. 4). These peaks were present but less evident in the trend for male recovery rate. Confidence intervals of recovery rate estimates indicate that recovery rates were greater in summer for females, but not for males, presumably because the estimates for females were more precise.

\section{Movement}

Results indicate frequent movements within the Cape Cod-Gulf of Maine and Georges Bank stock areas with less frequent movement among stock areas. Recapture data with known recapture locations indicate $96 \%$ residence in the Cape Cod-Gulf of Maine stock area (with $3 \%$ movement to the Georges Bank stock area and 1\%

Table 2

Annual data of release and recapture of tagged Yellowtail Flounder (Limanda ferruginea) used to estimate survival in this study of the mortality and movement of this species off New England.

\begin{tabular}{lcccrrrrr}
\hline \multirow{2}{*}{$\begin{array}{l}\text { Year } \\
\text { marked }\end{array}$} & $\begin{array}{l}\text { Number } \\
\text { marked }\end{array}$ & 2003 & 2004 & 2005 & 2006 & 2007 & $\begin{array}{c}\text { Total } \\
\text { recaptured }\end{array}$ & $\begin{array}{c}\text { Percentage } \\
\text { recaptured }\end{array}$ \\
\cline { 3 - 8 } 2003 & 10,122 & 526 & 403 & 72 & 18 & 3 & 1022 & 10.1 \\
2004 & 17,783 & & 628 & 492 & 96 & 18 & 1234 & 6.9 \\
2005 & 6084 & & & 440 & 96 & 23 & 559 & 9.2 \\
2006 & 9918 & & & & 490 & 152 & 642 & 6.5 \\
Totals & 43,907 & 526 & 1049 & 1004 & 700 & 196 & 3457 & 7.9 \\
& & & & & & & & \\
\hline
\end{tabular}




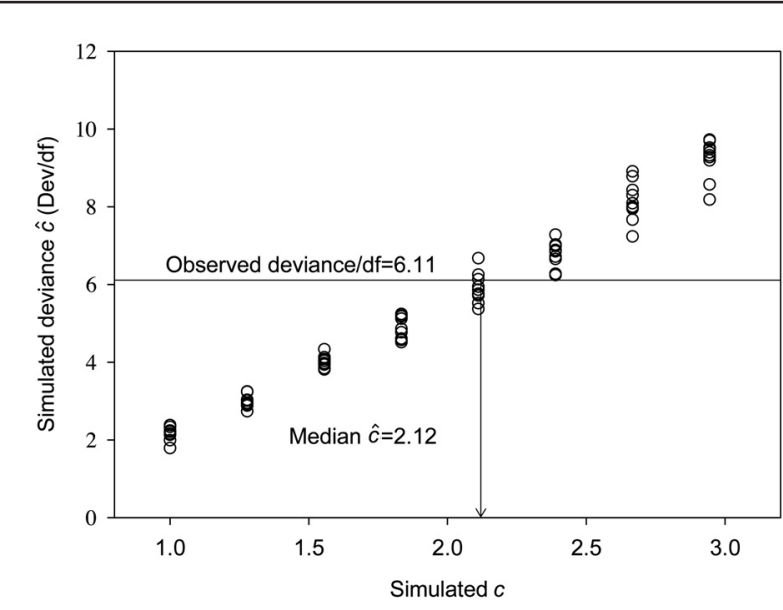

Figure 2

Results from a goodness-of-fit test used to estimate overdispersion $(\hat{c})$ for the general model fitted to tagrecovery data (time- and sex-dependent parameterization) for Yellowtail Flounder (Limanda ferruginea) tagged off New England from June 2003 to August 2006. The estimates of simulated deviance $\hat{c}$ are shown for a range of simulated $c$ values. The value of $\hat{c}$, determined through logistic regression, is the point (6.11) where $50 \%$ of the simulated values fall above and $50 \%$ fall below the observed deviance $\hat{c}$ for the general model. $\mathrm{df}=$ degrees of freedom. Dev=deviance.

movement to the southern New England-Mid-Atlantic stock area), 98\% residence on the Georges Bank stock area (with $1 \%$ movement to the Cape Cod-Gulf of Maine stock area and $<1 \%$ movement to the southern New England-Mid-Atlantic), and 26\% residence in the southern New England-Mid-Atlantic stock area (with 63\% movement to the Georges Bank stock area and $10 \%$ movement to the southern Cape Cod-Gulf of Maine stock area; Table 4). However, most movement from southern New England was observed for Yellow- tail Flounder released on Nantucket Shoals, near the boundary with adjacent stock areas (Fig. 5).

\section{Discussion}

The numbers of releases of tagged fish and tag recoveries in this study were 10 times greater than the numbers from any previous study of Yellowtail Flounder movement or mortality. The results from this study provide updated inferences of movement patterns and an independent estimate of mortality. Tag-recovery modeling and its application in fisheries research has increased in popularity over the past decade and has become an important tool to fisheries management (Pine et al., 2003). Large-scale tag-recapture studies provide insights into fish movement and population dynamics that are separate (except for their reliance on fishery recaptures) from the fishery-dependent and research survey data and methods used in conventional stock assessments. The results from tagging analyses should be of particular interest when there are suspected inconsistencies with the stock assessment data and analyses, as is the case for Yellowtail Flounder stocks off New England.

The results from tag-recovery modeling in this study are consistent with the perception that the Yellowtail Flounder resource in New England is experiencing an intense rate of mortality. The total annual mortality estimate of 1.4 derived from patterns of tag recovery is similar to stock-specific, age-based mortality estimates from the Yellowtail Flounder assessments for 2003 to 2006 (NEFSC $^{1}$; Fig. 3). The results from this study demonstrate that models typically used in quantitative ecology (e.g., the Brownie tag-recovery model) can complement conventional methods for fisheries stock assessment. The advantage of the Brownie model is that survival estimates are not conditional on an assumed natural mortality rate, and recovery rates are a composite of exploitation rate (i.e., natural and fishing

\section{Table 3}

The top 5 most highly ranked models adjusted for a $\hat{c}=2.12$ that were fitted to tag-recovery data in this study of the mortality and movement of Yellowtail Flounder (Limanda ferruginea) tagged off New England from 2003 to 2006. Models were ranked by quasi-likelihood adjusted AIC (QAIC $)_{c}$. Survival $(S)$ and recovery rate $(f)$ were estimated by month (t), for the entire time series (.), and by sex (g). The optimal model (in bold type) was chosen on the basis of rank and parameter estimates that were biologically reasonable.

\begin{tabular}{|c|c|c|c|c|c|c|}
\hline Model & $\mathrm{QAIC}_{\mathrm{c}}$ & $\begin{array}{c}\text { Delta } \\
\text { QAIC }_{\mathrm{c}}\end{array}$ & $\begin{array}{l}\text { QAIC }_{c} \\
\text { weight }\end{array}$ & $\begin{array}{c}\text { Model } \\
\text { likelihood }\end{array}$ & $\begin{array}{l}\text { Number of } \\
\text { Parameters }\end{array}$ & Qdeviance \\
\hline$S(\mathrm{t}) f(\mathrm{~g} * \mathrm{t})$ & 19765.56 & \multirow{2}{*}{\multicolumn{5}{|c|}{ Multiple boundary estimates for survival }} \\
\hline$S(\mathrm{t}) f(\mathrm{t})$ & 19813.70 & & & & & \\
\hline$S() f.(g * t)$ & 19825.54 & 0.00 & 0.73 & 1.00 & 111 & 1181.05 \\
\hline$S(\mathrm{~g}) f(\mathrm{~g} * \mathrm{t})$ & 19827.51 & 1.97 & 0.27 & 0.37 & 112 & 1181.01 \\
\hline$S(\mathrm{~g} * \mathrm{t}) f(\mathrm{t})$ & 19847.22 & 21.68 & 0.00 & 0.00 & 163 & 1098.07 \\
\hline
\end{tabular}




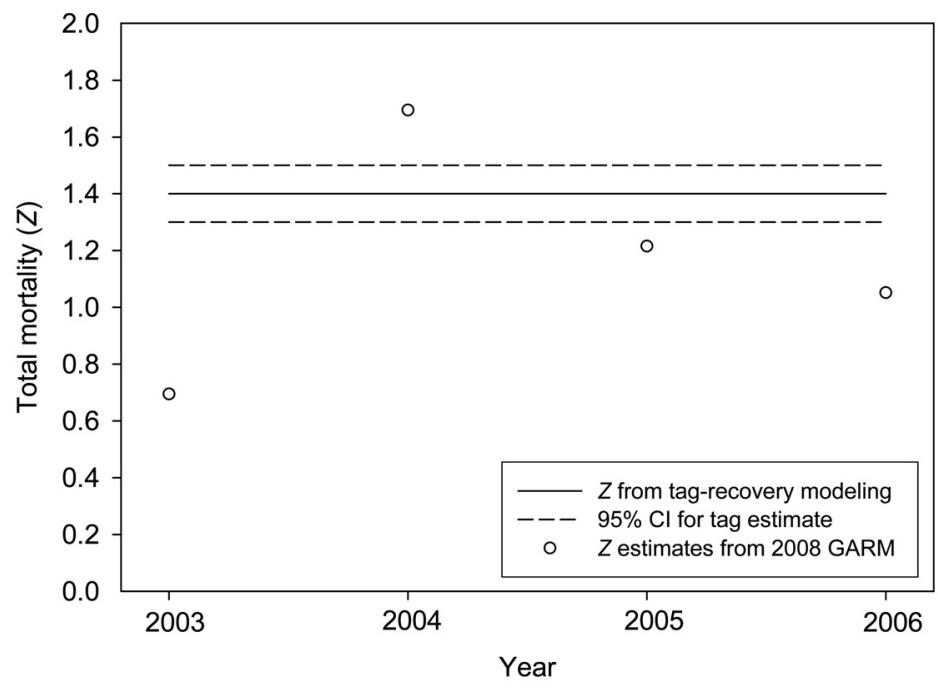

Figure 3

Estimates of total mortality $(Z)$, with $95 \%$ confidence intervals (CIs), of Yellowtail Flounder (Limanda ferruginea) from 2003 to 2006 from tag-recovery modeling in this study and the stock assessments from the 2008 Groundfish Assessment Review Meeting (GARM) of the Northeast Fisheries Science Center.

mortality), survival from the tagging process, tag retention, and tag reporting (Brownie et al., 1985).

The mortality estimates derived from the tagging data corroborate stock assessment estimates; however, tag estimates could be inflated if a model assumption was violated. For the tagging models, all marked fish were assumed to have the same probability of survival and recapture by the fishery. This assumption is often violated when newly released fish do not fully mix with the population and have a different recapture probability (Hoenig et al., 1998). A close examination of the full residual matrix for Yellowtail Flounder did not reveal any patterns consistent with nonmixing, which is typically represented with a consistent residual along the recovery diagonal (Latour et al., 2001). Tagging-induced effects, both directly induced mortality and short-term tag loss, also could affect survival estimates. Experiments with tanks and cages designed to test the tag retention and tag-induced mortality of Yellowtail Flounder have indicated that these effects were not a concern (Alade, 2008). Any possible influence from these 2 effects likely would remain constant throughout the study and would not influence the survival estimates significantly.

Finally, the tag-recovery models used in this study did not estimate tag loss and tags were assumed not lost or missed. A fish that loses its tag is equivalent to a dead fish when it comes to the estimation of survival (Brownie et al., 1985). The Peterson disc tags used in this study are secure tags that pass through the body of a flounder and are anchored on both the dorsal and ventral surfaces. These tags have been widely applied in fish tagging studies and are known for a very high retention rate (Thorsteinsson, 2002). In addition, a long-term holding study with some fish held for more than 1 year showed 100\% tag retention, and therefore tag loss was expected to be minimal (Alade, 2008).

Although the tag-recovery estimate of survival is consistent with results from agebased stock assessments, several aspects of this tagging study should be considered in future assessments. The difference in recovery rate between the sexes indicates that population dynamics may differ between males and females. The lower recovery rate of males could be a result of greater natural mortality - a finding that is consistent with sexually dimorphic growth rates and maximum sizes of Yellowtail Flounder (Lux and Nichy, 1969). However, sex-based recovery rates also could result from differences in catchability between sexes.

The possibility of substantial movement between stock areas (e.g., from southern New England to Georges Bank) may also influence population dynamics of Yellowtail Flounder (Hart and Cadrin, 2004). Analyses of simulated release and recapture data, with a data structure consistent to the data used in this study, indicate that movement and mortality cannot be simultaneously estimated because of highly correlated movement parameters (Alade, 2008). Therefore, simultaneous estimation of both movement and mortality may require an integrated analysis of data from tagging surveys, fisheries surveys, and resource surveys (Maunder, 2001; Goethel et al., 2010).

A summary of all published yellowtail flounder movements off the northeast United States, including those reported here, has revealed that juveniles and adults do not frequently move among fishing grounds (Cadrin, 2010). The movement from the southern New England-Mid-Atlantic stock area to the Georges Bank stock area observed in the study described in this article is greater than the movement reported in previous studies. However, most releases in the southern New England-Mid-Atlantic stock area were near the boundary because that location was the only one sampled in the stock area that had high densities of Yellowtail Flounder. The pattern of tag recoveries (Fig. 5) and previous analyses of movement trends from surveys (Cadrin, 2010) indicate that the southwestern portion of Georges Bank and Nantucket Shoals is an area of stock mixing, and that relative stock size may influence stock composition in that area. Although the study described here was not designed to estimate seasonal movement, the results of this research are consistent with those of previous tagging studies of Yellowtail Flounder off New 


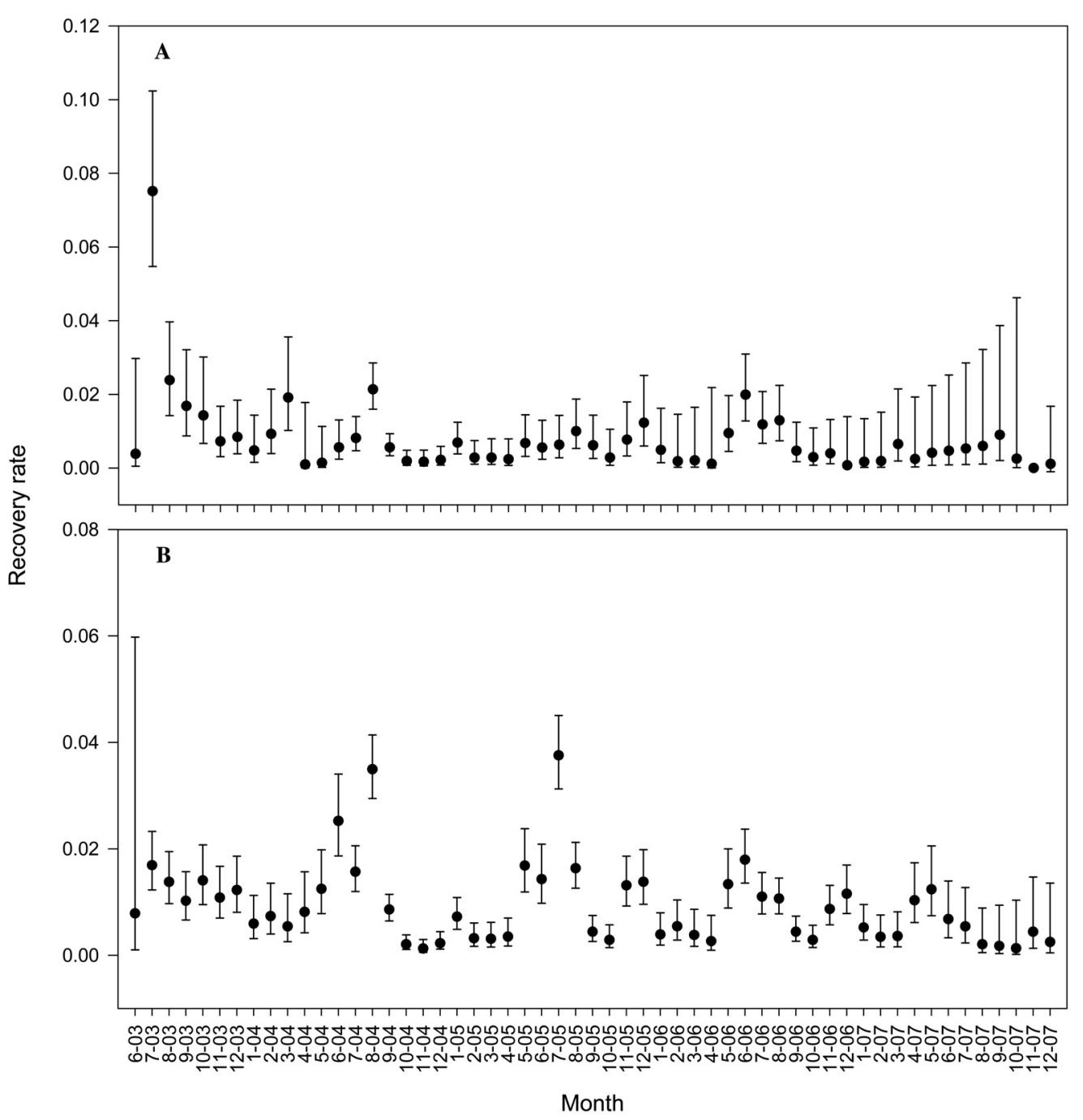

Figure 4

Recovery-rate probabilities by month for (A) male and (B) female Yellowtail Flounder (Limanda ferruginea) from the optimal model used in this study of the mortality and movement of this species from 2003 to 2006 off New England. The optimal model was the model with a constant survival and time- and sex-dependent recovery rate. Error bars represent 95\% confidence intervals.

England that have indicated short, seasonal movement patterns (Royce et al., 1959; Lux, 1963).

\section{Conclusions}

Current stock assessments of Yellowtail Flounder provide valuable information for fishery management, although several major sources of uncertainty are present $\left(\mathrm{NEFSC}{ }^{1}\right)$. The results of this study address $2 \mathrm{im}$ portant sources of uncertainty in the Yellowtail Flounder assessments: estimates of mortality and large-scale movement patterns among stock areas.
The results from the tag-recovery modeling in this study confirm that the Yellowtail Flounder population is experiencing a high level of mortality. These results were derived from data independent of the stock assessment data, and although we were able to confirm high levels of mortality, the direct cause remains unknown. In addition to modeling mortality, the pattern of tag-recovery locations from this study provides an updated look at stock mixing. Movement from the southern New England-Mid-Atlantic stock area to the Georges Bank stock area was greater than previously observed. However, some of this perceived movement was attributed to the study design and the locations 


\section{Table 4}

Residence and movement of tagged Yellowtail Flounder (Limanda ferruginea) from 2003 to 2006 among managed stock areas off New England. Three stock areas were used in this study: Cape CodGulf of Maine (CC-GOM), Georges Bank (GB), and southern New England-Mid-Atlantic (SNE-MA).

\begin{tabular}{lrrrrrrrrr}
\hline & \multicolumn{3}{c}{ Recapture area } & & & \multicolumn{3}{c}{ Recapture percentage } \\
\cline { 2 - 4 } Release area & CC-GOM & GB & SNE-MA & & Total & & CC-GOM & GB & SNE-MA \\
\hline CC-GOM & 1049 & 38 & 10 & & 1097 & & 0.96 & 0.03 & 0.01 \\
GB & 32 & 2307 & 11 & & 2350 & & 0.01 & 0.98 & 0.01 \\
SNE-MA & 14 & 86 & 36 & & 136 & & 0.10 & 0.63 & 0.26 \\
$\quad$ Total & 1095 & 2431 & 57 & & 3583 & & & \\
\end{tabular}

where tagged fish were released. Tag-recovery patterns indicate that Yellowtail Flounder carried out frequent movements within stock areas and less frequent movement between areas. It is unlikely that uncertainties in the Yellowtail Flounder assessments are a result of substantial movement between stock areas.
This study provides insight into important uncertainties associated with the population dynamics of Yellowtail Flounder stocks off New England. The results from this study can be used to inform future assessments and provide additional information to aid in the management of this species.

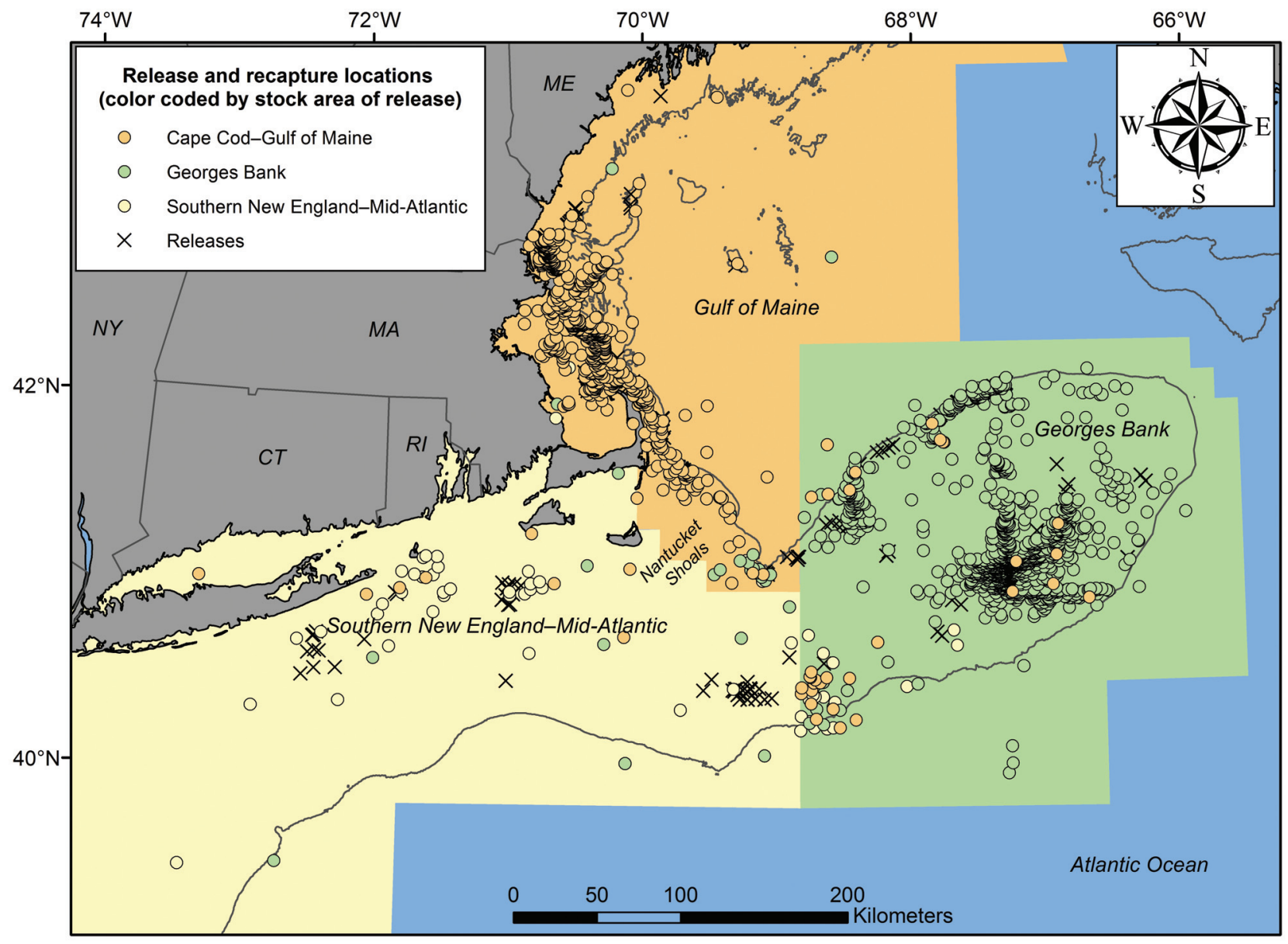

Figure 5

Map of the locations of release and recovery of tagged Yellowtail Flounder (Limanda ferruginea) in 3 stock areas off New England from 2003 to 2006. Recaptures are color-coded on the basis of the stock area where they were tagged and released. The 3 stock areas examined in this study were Cape Cod-Gulf of Maine (gold block), Georges Bank (green block), and southern New England-Mid-Atlantic (yellow block). 


\section{Acknowledgments}

Fishermen and researchers cooperated to develop the general approach and technical details of this tagging study. Many fishermen have contributed to this study, including 3 who were involved in all aspects of planning and decision-making: D. Goethel, R. Avila, and F. Mattera. Many scientists collaborated on this study, helping with tagging and other at-sea work, data modeling and analyses, and database development and maintenance. Specific thanks go to A. Westwood, J. Moser, L. Alade, D. Martins, G, DeCelles, D. Goethel, T. Miller, S. Kubis, and C. Sumi. This study was funded by the Northeast Consortium, the Northeast Cooperative Research Program of the Northeast Fisheries Science Center, the NMFS Stock Assessment Improvement Program, and the Massachusetts Marine Fisheries Institute.

\section{Literature cited}

Alade, L.

2008. A simulation-based approach for evaluating the performance of a yellowtail flounder (Limanda ferruginea) movement-mortality model. Ph.D. diss., 316 p. Univ. Maryland Eastern Shore, Princess Anne, MD.

Anderson, D. R., K. P. Burnham, and G. C. White. 1994. AIC model selection in overdispersed capture-recapture data. Ecology 75:1760-1793.

Brownie, C., D. R. Anderson, K. P. Burnham, and D. S. Robson. 1985. Statistical inference from band recovery data: a handbook, $2^{\text {nd }}$ ed., 305 p. U.S. Fish Wildl. Serv. Resour. Publ. 156.

Burnham, K. P., and D. R. Anderson.

2002. Model selection and multimodel inference: a practical information-theoretic approach, $2^{\text {nd }} \mathrm{ed}, 488 \mathrm{p}$. Springer-Verlag, New York.

Cadrin, S. X.

2010. Interdisciplinary analysis of yellowtail flounder stock structure off New England. Rev. Fish. Sci. 18:281-299.

Collette, B. B., and G. Klein-MacPhee.

2002. Bigelow and Schroeder's fishes of the Gulf of Maine, $3^{\text {rd }}$ ed, 748 p. Smithsonian Inst. Press, Washington, D.C.

Goethel, D., T. J. Quinn II, and S. X. Cadrin.

2010. Incorporating spatial structure in stock assessment: movement modeling in marine fish population dynamics. Rev. Fish. Sci. 19: 119-136.

Hart, D., and S. X. Cadrin.

2004. Yellowtail flounder (Limanda ferruginea) off the northeastern United States, implications of movement among stocks. In Species conservation and management: case studies (H. R. Akçakaya, M. A. Burgman, O. Kindvall, C. C. Wood, P. Sjögren-Gulve, J. S. Hatfield, and M. A. McCarthy, eds.), p. 230-244. Oxford Univ. Press, New York.
Hoenig, J. M., N. J. Barrowman, K. H. Pollock, E. N. Brooks, W.

S. Hearn, and T. Polacheck.

1998. Models for tagging data that allow for incomplete mixing of newly tagged animals. Can. J. Fish. Aquat. Sci. 55:1477-1483.

Latour, R. J., J. M. Hoenig, J. E. Olney, and K. H. Pollock.

2001. Diagnostics for multiyear tagging models with application to Atlantic striped bass (Morone saxatilis). Can. J. Fish. Aquat. Sci. 58:1716-1726.

Lebrenton, J. D., K. P. Burnham, J. Clobert, and D. R. Andersen. 1992. Modeling survival and testing biological hypotheses using marked animals: a unified approach with case studies. Ecol. Monogr. 62:67-118.

Lux, F. E.

1963. Identification of New England yellowtail flounder groups. Fish. Bull. 63:1-10.

Lux, F. E., and F. E. Nichy.

1969. Growth of Yellowtail Flounder, Limanda ferruginea (Storer), on three New England fishing grounds. ICNAF Res. Bull. 6: 5-25.

Maunder, M. N.

2001. Integrated tagging and catch-at-age analysis (ITCAAN). In Spatial processes and management of fish populations (G. H. Kruse, N. Bez, A. Booth, M.W. Dorn, S. Hills, R. N. Lipcius, D. Pelletier, C. Roy, S. J. Smith, and D.Witherell, eds.), p. 123-146. Alaska Sea Grant College Program Report AK-SG-0102, Univ. Alaska, Fairbanks, AK.

NMFS (National Marine Fisheries Service).

2012. Fisheries of the United States 2011. Current Fishery Statistics No. 2011, 125 p. Fisheries Statistics Div., Office of Science and Technology, NMFS, Silver Spring, MD.

Pine, W. E., K .H. Pollock, J. E. Hightower, T. J. Kwak, and J. A. Rice.

2003. A review of tagging methods for estimating fish population size and components of mortality. Fisheries 28(10):10-23.

Royce, W. F., R. J. Buller, and E. D. Premetz.

1959. Decline of the yellowtail flounder (Limanda ferruginea) off New England. Fish. Bull. 59:169-267.

Sokal, R. R., and F. J. Rohlf.

1995. Biometry: the principles and practice of statistics in biological research, $3^{\text {rd }}$ ed., 880 p. W.H. Freeman, New York.

Thorsteinsson, V.

2002. Tagging methods for stock assessment and research in fisheries. Report of Concerted Action FAIR CT.96.1394 (CATAG), 179 p. Mar. Res. Inst. Tech. Report 79. Marine Research Institute, Reykjavik, Iceland.

Walsh, S. J., and M. J. Morgan.

2004. Observations of natural behavior of yellowtail flounder derived from data storage tags. ICES J. Mar. Sci. 61:1151-1156.

White, G. C., and Burnham, K. P.

1999. Program MARK: survival estimation from populations of marked animals. Bird Study 46:120138. 